\title{
Penerapan Model Pembelajaran Berbasis Masalah dengan Bantuan Media Video untuk Meningkatkan Keterampilan Menulis Teks Eksplanasi
}

\author{
Justianus Tarigan* \\ Jurusan Pendidikan Bahasa Indonesia, Bali Indonesia
}

A R T I C L E I N F O

Article history:

Received 15 Maret

2018

Received in revised

form

25 Maret 2018

Accepted 10 April

2018

Available online 20

Mei 2018

\author{
Kata Kunci: \\ model pembelajaran \\ berbasis masalah, \\ media video, menulis \\ teks eksplanasi \\ Keywords: \\ problem-based \\ learning model, video \\ media, writing \\ explanatory text
}

\begin{abstract}
A B S T R A K
Penelitian ini adalah penelitian tindakan kelas yang bertujuan untuk meningkatkan keterampilan menulis teks eksplanasi melalui penerapan model pembelajaran berbasis masalah dengan bantuan media video. Subjek penelitian ini adalah siswa kelas XI IIS SMA Negeri 1 Singaraja semester gasal tahun pembelajaran 2017/2018 yang berjumlah 18 orang. Data penelitian ini terbagi menjadi tiga, yakni hasil menulis teks eksplanasi, langkah-langkah penerapan model pembelajaran berbasis masalah dengan bantuan media video, dan respons siswa terhadap pembelajaran. Data hasil menulis teks eksplanasi oleh siswa dikumpulkan dengan teknik tes, data langkahlangkah penerapan model pembelajaran berbasis masalah dengan bantuan media video dikumpulkan dengan observasi, dan data respons siswa terhadap pembelajaran dikumpulkan dengan angket. Data hasil menulis teks eksplanasi oleh siswa dianalisis dengan teknik deskriptif kuantitatif. Data langkah-langkah penerapan model pembelajaran berbasis masalah dengan bantuan media video dianalisis dengan teknik deskriptif kualitatif. Data respons siswa terhadap pembelajaran dianalisis dengan teknik deskriptif kualitatif. Hasil ini menunjukkan bahwa keterampilan menulis teks eksplanasi siswa mengalami peningkatan. Respons siswa terhadap pembelajaran berada pada kategori sangat baik, yakni $89 \%$ siswa mengganggap positif pada siklus I dan $85 \%$ siswa mengganggap positif pada siklus II.
\end{abstract}

\section{A B S T R A C T}

This research is a classroom action research that aims to improve the skills of writing explanatory text through the application of problem-based learning model with the help of video media. The subjects of this study are the students of class XI IIS SMA Negeri 1 Singaraja odd semester in academic year 2017/2018 study which amounted to 18 people. This research data is divided into three, namely the writing of explanatory text, the steps of applying problem-based learning model with the help of video media, and student's response to learning. The result data of the explanatory text by the students was collected by the test technique, the data of the steps of applying the problem-based learning model with the help of video media were collected by observation, and the student's response data to the learning was collected by questionnaire. The data of writing explanatory text by the students is analyzed by quantitative descriptive technique. Data on the implementation of problembased learning model with the help of video media is analyzed by qualitative descriptive technique. Student response data on learning is analyzed by qualitative descriptive technique. These results indicate that the writing skills of students' explanatory text has increased.. Student responses in learning were in very good category, ie $89 \%$ of students assume positive in cycle I and $85 \%$ of students assume positive in cycle II. 


\section{Pendahuluan}

Pembelajaran bidang studi Bahasa Indonesia bertujuan agar siswa terampil dalam berkomunikasi, baik lisan maupun tulisan karena memang pada hakikatnya fungsi utama bahasa adalah sebagai alat komunikasi. Selain sebagai alat komunikasi, bahasa juga merupakan saluran perumusan maksud, melahirkan perasaan, dan memungkinkan seseorang menjalin kerja sama (Natalia, 2017). Oleh karena itu, pembelajaran bahasa ditujukan untuk meningkatkan keterampilan berpikir, mengungkapkan gagasan, pikiran, perasaan, pendapat, menyampaikan informasi tentang suatu peristiwa, dan menambah wawasan. Dalam Kurikulum 2013 ini Bahasa Indonesia digunakan sebagai sarana untuk mengembangkan kemampuan dan keterampilan menalar hingga nantinya tercapai keterampilan berbahasa yang diinginkan (Agustini, 2016). Pembelajaran bahasa Indonesia berbasis teks memiliki implikasi terhadap pelaksanaan pembelajaran yang tidak terlepas dari teks dalam bentuk lisan maupun tulisan (Ulfah, 2014). Menulis merupakan salah satu keterampilan berbahasa yang ditekankan dalam pembelajaran Bahasa Indonesia pada Kurikulum 2013. Sebagai salah satu keterampilan berbahasa, keterampilan menulis perlu diperhatikan karena merupakan keterampilan berbahasa yang bersifat produktif dan ekspresif yang sangat diperlukan untuk memenuhi kebutuhan komunikasi sehari-hari (Sriani, 2015). Menulis merupakan seni mengekspresikan ide atau perasaan melalui tulisan, seperti halnya pelukis yang menuangkan ide atau perasaannya ke dalam bentuk lukisan (Somodana, 2015).

Kemampuan menulis menuntut sejumlah pengetahuan dan keterampilan. Untuk menulis sebuah karangan sederhana pun secara teknik penulis diharapkan dapat memenuhi persyaratan dasar, seperti menulis karangan yang rumit. Penulis harus memilih topik, membatasinya, mengembangkan gagasan, dan menyajikannya dalam kalimat dan paragraf yang tersusun secara logis (Ramadhanti, 2017). Menulis teks eksplanasi merupakan salah satu tuntutan kurikulum 2013 pada pembelajaran Bahasa Indonesia untuk siswa SMA kelas XI. Menulis teks eksplanasi tertuang pada kompetensi dasar poin 4.4 yang berbunyi "Memproduksi teks eksplanasi secara lisan atau tulis dengan memerhatikan struktur dan kebahasaan" (Kemdikbud, 2016). Oleh sebab itu, siswa SMA kelas XI harus mampu menulis teks eksplanasi dengan baik sesuai dengan ketentuan teks tersebut. Teks eksplanasi adalah teks yang menekankan pada proses atau sebab akibat terjadinya sebuah bencana alam, proses sosial, dan perkembangan ilmu pengetahuan. Isi teks eksplanasi mampu menjawab pertanyaan "mengapa" dan "bagaimana" suatu fenomena terjadi (Priyatni dalam Oktarina, 2015).

Pembelajaran Bahasa Indonesia materi menulis teks eksplanasi tergolong materi yang serius dan cukup sulit bagi siswa SMA karena disebabkan oleh-Pertama, menulis belum menjadi sebuah kebiasaan siswa sehingga siswa kesulitan saat memulai menulis dan mengembangkan tulisan menjadi tulisan yang utuh. Hal ini juga ada hubungannya dengan tingkat kegemaran siswa membaca. Kedua, materi menulis teks eksplanasi adalah materi menulis nonfiksi yang sangat terikat pada aturan penulisan sehingga siswa harus berhati-hati dalam menulis. Ini tentu berbeda dengan menulis sastra yang terkesan lebih longgar terhadap aturan penulisan. Ketiga, teks eksplanasi harus memperhatikan struktur dan ciri kebahasaan. Poin ketiga ini merupakan poin yang paling penting karena struktur dan ciri kebahasaanlah yang membedakan antara teks eksplanasi dengan teks lain.

Siswa kelas XI IIS SMA Negeri 1 Singaraja pada saat dilakukan wawancara menyatakan bahwa mereka mengalami kesulitan menulis teks eksplanasi. Penyebab kesulitan menulis teks ini karena berbagai hal, yakni banyak menggunakan istilah ilmiah dan bahasa baku, keterbatasan pengetahuan, ide, dan gagasan dalam menyusun teks eksplanasi, kurang memahami struktur dan ciri kebahasaan teks eksplanasi, kesulitan dalam menjabarkan kalimat utama menjadi kalimat penjelas, dan siswa kurang termotivasi menghasilkan teks eksplanasi karena merasa tidak mendapat manfaat nyata dari materi ini.

Hasil wawancara di atas sejalan dengan yang disampaikan oleh guru bidang studi bahasa Indonesia yang mengajar di kelas XI IIS SMA Negeri 1 Singaraja. Guru bidang studi mengakui bahwa keterampilan menulis teks siswa tergolong rendah terkhusus pada keterampilan menulis teks eksplanasi. Kesulitan terbesar siswa terletak pada mengembangkan paragraf. Bahkan sering ditemukan siswa membuat teks hanya satu paragraf. Selain itu, kesalahan yang ditemukan pada teks buatan siswa adalah kesalahan penggunakan ejaan. Diperoleh dari hasil penelitian yang dilakukan oleh Ariningsih, dkk dalam jurnal yang berjudul Analisis Kesalahan Berbahasa Indonesia dalam Karangan Eksposisi Siswa Sekolah Menengah Atas (2012: 41), "Masalah dalam menulis juga dihadapi siswa antara lain: (1) sulit menentukan tema; (2) keterbatasan informasi yang disebabkan kurangnya referensi; (3) adanya rasa malas atau bosan; (4) penguasaan kaidah yang kurang baik."

Hasil wawancara dengan guru bidang studi juga ditemukan beberapa hal yang dikira penting untuk membuat sebuah langkah pemecahan masalah siswa terkait rendahnya hasil belajar menulis teks eksplanasi. Guru bidang studi mengatakan bahwa siswa memiliki motivasi belajar yang baik dan punya kemauan yang kuat untuk menyelesaikan sebuah permasalahan. 
Berbagai temuan yang telah diperoleh seperti yang dikemukakan sebelumnya, baik kesulitan siswa dalam menulis teks eksplanasi maupun motivasi belajar siswa yang baik sehingga masalah ini perlu dicarikan solusinya. Dengan mengedepankan kelebihan siswa, yakni memiliki kemauan kuat untuk menyelesaikan masalah, permasalahan ini diasumsikan dapat diatasi dengan penerapan suatu model pembelajarn. Model pembelajaran berfungsi sebagai pedoman bagi para perancang pembelajaran dan para pengajar dalam merencanakan aktivitas belajar mengajar (Sariada, 2014). Model pembelajaran digunakan guru sebagai acuan untuk menciptakan suasana pembelajaran yang aktif, kreatif, edukatif, dan menyenangkan (PAKEM) (Saadah, 2017). Model pembelajaran ada bermacam-macam jenisnya salah satunya adalah model pembelajaran berbasis masalah. Dalam kurikulum 2013, pembelajaran berbasis masalah merupakan salah satu model yang disarankan untuk dapat diterapkan oleh guru pada saat pembelajaran. Penerapan model pembelajaran berbasis masalah dalam pembelajaran dapat mengaktifkan siswa dalam proses pembelajaran, dimana siswa terlibat secara langsung dalam proses penemuan pemahaman materi yang diajarkan, sehingga siswa dapat lebih memahami materi yang diajarkan guru (Andriani, 2015).

Model pembelajaran berbasis masalah (problem based learning disingkat PBL) adalah model pembelajaran yang menuntut aktivitas mental siswa untuk memahami suatu konsep pembelajaran melalui situasi dan masalah yang disajikan pada awal pembelajaran dengan tujuan untuk melatih siswa menyelesaikan masalah dengan menggunakan pendekatan pemecahan masalah (Utomo,dkk, 2014). Pembelajaran berdasarkan masalah adalah suatu model pembelajaran yang didasarkan pada prinsip menggunakan masalah sebagai titik awal akuisisi dan integrasi pengetahuan baru (Primiani, 2012). PBL merupakan model pembelajaran inovatif yang dapat memberikan kondisi belajar aktif kepada siswa. Dimana siswa dapat secara aktif berfikir dalam menyelesaikan masalah yang berkaitan dengan kehidupan sosial mereka. Model pembelajaran PBL bermanfaat untuk membantu siswa belajar secara mandiri dan memberikan pengalaman dalam menyelesaikan masalah sehari-hari yang mendorong berkembangnya pola pikir dan pola kerja seseorang dalam membelajarkan dirinya.

Selain penerapan model PBL, solusi yang ditawarkan adalah penerapan media video. Jadi, model PBL akan dipadukan dengan media video untuk meningkatkan keterampilan menulis teks eksplanasi siswa. Media video dinyatakan tepat untuk meningkatkan keterampilan menulis teks eksplansi berpadu dengan model pembelajaran PBL karena video memiliki keunggulan dibandingkan media lain. Media video mampu memperjelas sajian ide dan mengilustrasikannya sehingga siswa tidak cepat lupa. Sajian ide yang jelas dan terilustrasi dengan baik inilah yang sangat berguna bagi siswa dalam menuliskan teks eksplanasi. Selain itu, media video dapat menarik minat dan perhatian siswa. Yang tidak kalah penting adalah video termasuk media yang relatif murah saat ini, baik harga maupun pengoperasiannya, serta alatnya tersedia di sekolah.

Hal ini sejalan dengan penelitan yang dilakukan oleh Idrus (2015) yang menunjukkan bahwa model pembelajaran berbasis masalah berbantuan video kartun berpengaruh terhadap hasil belajar fisika siswa kelas XI SMAN 1 Sikur. Penelitian oleh Putri (2017) yang menunjukkan adanya pengaruh yang signifikan pada model problem based learning berbantuan video terhadap keterampilan berpikir kritis. Dewi (2013) mengatakan model pembelajaran PBL berbantuan media video lebih unggul dibandingkan dengan model pembelajaran konvensional terhadap hasil belajar IPA.

\section{Metode}

Penelitian ini dilaksanakan di SMA Negeri 1 Singaraja. Penelitian ini adalah penelitian tindakan kelas (classroom action research) dengan dua siklus. Setiap siklus melalui tahapan perencanaan, pelaksanaan, observasi/evaluasi, dan refleksi. Data penelitian ini terbagi atas tiga bagian, yaitu hasil belajar siswa menulis teks eksplanasi, langkah-langkah penerapan model pembelajaran berbasis masalah dengan bantuan media video untuk meningkatkan keterampilan menulis teks eksplanasi siswa, dan renspons siswa terhadap pembelajaran. Subjek penelitian ini adalah siswa kelas XI IIS SMA Negeri 1 Singaraja semester gasal tahun pembelajaran 2017/2018 yang berjumlah 18 orang. Obyek dari penelitian ini adalah keterampilan menulis teks eksplanasi.

Data berupa hasil belajar siswa menulis teks eksplanasi akan diambil dengan menggunakan teknik tes dan instrumennya adalah soal uraian. Data berupa langkah-langkah penerapan model pembelajaran berbasis masalah dengan bantuan media video untuk meningkatkan keterampilan menulis teks eksplanasi siswa akan diambil dengan menggunakan teknik observasi dan instrumennya adalah lembar observasi. Terakhir, data berupa renspons siswa terhadap pembelajaran akan diambil dengan cara teknik angket dan instrumennya adalah lembar angket. Data hasil menulis teks eksplanasi oleh siswa dianalisis dengan teknik deskriptif kuantitatif. Data langkah-langkah penerapan model pembelajaran berbasis masalah 
dengan bantuan media video dianalisis dengan teknik deskriptif kualitatif. Data respons siswa terhadap pembelajaran dianalisis dengan teknik deskriptif kualitatif.

\section{Hasil dan Pembahasan}

\section{Hasil}

Siklus I melewati tahapan perencanaan, pelaksanaan, observasi/evaluasi, dan refleksi. Pada tahap perencanaan, peneliti dengan guru pamong secara kolaborasi menyusun rencana pelaksanaan pembelajaran, mempersiapkan media pembelajaran, mempersiapkan instrumen penelitian, dan mempersiapkan lembar kerja siswa. Pada tahap pelaksanaan, peneliti mengaplikasikan RPP yang sudah disusun dengan guru pamong sesuai dengan sintaks pembelajaran menurut model PBL. Pada tahap observasi/evaluasi, seorang teman sejawat yang menjadi observer yang melakukan observasi terhadap jalannya pembelajaran di kelas. Observer melakukan pengamatan dengan panduan yang disediakan. Observer sengaja diambil dari teman sejawat agar hasil yang didapatkan benar-benar valid. Selanjutnya, pada bagian evaluasi, peneliti meminta siswa menulis teks eksplanasi berdasarkan media video yang ditayangkan. Selain itu, siswa juga diminta mengisi angket respons terhadap pembelajaran.

Sebelum masuk ke tahap refleksi, penelitian siklus I ini telah memperoleh tiga data penting dalam penelitian ini, yakni hasil belajar siswa dalam menulis teks eksplanasi, langkah-langkah penerapan model pembelajaran PBL dengan bantuan media video, dan respons siswa terhadap pembelajaran. Hasil belajar siswa menulis teks eksplanasi digambarkan seperti pada tabel di bawah ini.

Tabel 1. Hasil belajar siswa menulis teks eksplanasi siklus I

\begin{tabular}{cccc}
\hline No & NIS & Nilai & Keterangan \\
\hline 1 & 13810 & 75 & Tidak Lulus KKM \\
2 & 13812 & 72 & Tidak Lulus KKM \\
3 & 13814 & 68 & Tidak Lulus KKM \\
4 & 13803 & 85 & Lulus KKM \\
5 & 13806 & 76 & Tidak Lulus KKM \\
6 & 13807 & 87 & Lulus KKM \\
7 & 13808 & 68 & Tidak Lulus KKM \\
8 & 13816 & 69 & Tidak Lulus KKM \\
9 & 13809 & 74 & Tidak Lulus KKM \\
10 & 13801 & 90 & Lulus KKM \\
11 & 13805 & 84 & Lulus KKM \\
12 & 13813 & 72 & Tidak Lulus KKM \\
13 & 13800 & 80 & Tidak Lulus KKM \\
14 & 13802 & 94 & Lulus KKM \\
15 & 13815 & 70 & Tidak Lulus KKM \\
16 & 13899 & 71 & Tidak Lulus KKM \\
17 & 13811 & 76 & Tidak Lulus KKM \\
18 & 13804 & 83 & Lulus KKM \\
\hline
\end{tabular}

Hasil belajar siswa menulis teks eksplansi pada siklus I pada Tabel I dikonvesikan ke dalam skala lima pada Tabel 2.

Tabel 2. Skala lima

\begin{tabular}{lll}
\hline Rentang nilai & Kategori & Jumlah siswa \\
\hline $91-100$ & Sangat Baik & 1 \\
$81-90$ & & 5 \\
$71-80$ & Baik & 8 \\
$61-70$ & & 4 \\
$51-60$ & Cukup Baik & \\
$41-50$ & & \\
$31-40$ & Kurang Baik & \\
$21-30$ & & \\
$11-20$ & Tidak Baik & \\
\hline
\end{tabular}




\begin{tabular}{ll}
\hline $1-10$ & \\
Nilai rerata & 77,4 \\
Nilai KKM & 82 \\
Siswa lulus KKM & 6 \\
Siswa Tidak Lulus KKM & 12 \\
Persentasi ketuntasan klasikal & $33,3 \%$ \\
\hline
\end{tabular}

Tabel di atas menunjukkan bahwa keterampilan menulis siswa berada pada kategori baik dan sangat baik. Namun, harus dipahami bahwa nilai KKM kelas XI di SMA Negeri 1 Singaraja sebesar 82 sehingga siswa yang mendapat kategori nilai baik belum lulus KKM. Berdasarkan tabel di atas, nilai rerata keterampilan menulis teks eksplanasi siswa pada siklus I sebesar 77,4 dan ketuntasan klasikal sebesar $33,3 \%$. Hasil ini sebenarnya masih jauh dari target, yakni ketuntasan klasikal sebesar $80 \%$.

Langkah-langkah penerapan model pembelajaran PBL dengan bantuan media video mengikuti RPP yang disusun oleh peneliti dengan guru pamong secara kolaboratif. Berdasarkan pengamatan observer pada saat pembelajaran, secara keseluruhan peneliti telah melaksanakan langkah-langkah pembelajaran sesuai RPP yang disusun.

Respons siswa terhadap pembelajaran menunjukkan bahwa sebesar $89 \%$ siswa memberikan respons positif. Angka ini termasuk dalam kategori sangat baik. Artinya, siswa menganggap pembelajaran sangat bermakna bagi mereka. Berdasarkan hasil penelitian siklus I yang telah dipaparkan sebelumnya, siklus I ini belum mampu meningkatkan keterampilan menulis teks eksplanasi siswa. Sesuai dengan rancangan awal yang telah disusun bahwa penelitian akan diberhentikan jika keterampilan menulis teks eksplanasi siswa mencapai ketuntasan klasikal sebesar $80 \%$. Oleh sebab itu, pada tahap refleksi peneliti dan guru pamong akhirnya menyepakati bahwa penelitian ini dilanjutkan ke siklus II.

Belum berhasilnya penelitian pada siklus I ini diinterpretasikan karena ada beberapa konsep menulis teks eksplanasi yang belum dipahami oleh siswa dengan baik. Konsep yang dimaksudkan ini diidentifikasi sebagai penyebab kurang berhasilnya siswa dalam menulis teks eksplanasi. Penyebab yang dimaksud adalah sebagai berikut. 1) Siswa belum sepenuhnya mengikuti kerangka tulisan saat menulis teks sehingga tulisannya tidak terstruktur, 2) Siswa tampak kesulitan mengembangkan ide pokok paragraf. Terlihat pada tulisannya yang sering menggabungkan dua ide pokok paragraf menjadi satu paragraph, 3) Siswa belum memahami penggunaan kalimat efektif. Terlihat pada tulisannya yang panjangpanjang dan berbelit-belit. Bahkan, hanya satu kalimat dalam satu paragraph, 4) Siswa sering terbalik dalam penggunaan kata depan di dan imbuhan $d i-$, 5) Siswa belum memahami sepenuhnya aturan penulisan huruf kapital pada tulisan.

Berpedoman pada beberapa penyebab kesulitan siswa di atas, siklus II akan diawali dengan membahas hal ini. Tujuannya agar siswa memperoleh konsep yang benar tentang kesalahan yang telah dilakukannya pada siklus sebelumnya. Untuk itu, dilakukan beberapa perbaikan pada siklus II. Perbaikan yang dilakukan adalah sebagai berikut. (1) Siswa akan diarahkan untuk mencermati ulang pertanyaan yang wajib diisi oleh siswa setelah menonton video. Pertanyaan itu sesungguhnya adalah kerangka teks eksplanasi yang akan disusun siswa. Untuk itu, siswa wajib memahami maksud pengerjaan LKS itu dan siswa wajib memahami kerangka teks berdasarkan LKS yang dikerjakannya, (2) Siswa akan dibimbing untuk mampu menyusun kalimat penjelas berdasarkan kalimat utama yang disediakan menjadi sebuah paragraph, (3)Siswa akan dibimbing untuk memperbaiki kalimat yang tidak efektif menjadi kalimat efektif, (4) Siswa akan dibimbing mengenai penggunaan kata depan di dan imbuhan di-, (5) Siswa akan dibimbing mengenai penggunaan huruf kapital pada kalimat.

\section{Siklus II}

Siklus II penelitian ini juga melewati tahapan perencanaan, pelaksanaan, observasi/evaluasi, dan refleksi. Sebelum memasuki siklus II, peneliti dengan guru pamong secara kolaborasi melakukan perbaikan atas masukan dari hasil refleksi siklus I. Namun, dalam hal perencanaan tidak ada hal yang mendasar yang berubah. Pada perencanaan ini peneliti bersama guru pamong menyusun rencana pelaksanaan pembelajaran, mempersiapkan media pembelajaran, mempersiapkan instrumen penelitian, dan mempersiapkan lembar kerja siswa.

Pada tahap pelaksanaan, peneliti mengaplikasikan RPP yang sudah disusun dengan guru pamong sesuai dengan sintaks pembelajaran menurut model PBL. Pada tahap inilah peneliti memperbaiki kesalahan konsep seperti yang dipaparkan pada bagian refleksi siklus I. Kemudian, pada tahap observasi/evaluasi, seorang teman sejawat yang menjadi observer yang melakukan observasi terhadap jalannya pembelajaran di kelas. Selanjutnya, pada bagian evaluasi, peneliti meminta siswa menulis teks 
eksplanasi berdasarkan media video yang ditayangkan. Selain itu, siswa juga diminta mengisi angket respons terhadap pembelajaran.

Data yang diperoleh berdasarkan hasil belajar siswa menulis teks eksplanasi pada siklus II ini dipaparkan seperti yang terlihat pada tabel berikut ini.

Tabel 3. Hasil belajar siswa menulis teks eksplanasi siklus II

\begin{tabular}{|c|c|c|c|}
\hline No & NIS & Nilai & Keterangan \\
\hline 1 & 13810 & 89 & Lulus KKM \\
\hline 2 & 13812 & 86 & Lulus KKM \\
\hline 3 & 13814 & 74 & Tidak Lulus KKM \\
\hline 4 & 13803 & 96 & Lulus KKM \\
\hline 5 & 13806 & 96 & Lulus KKM \\
\hline 6 & 13807 & 96 & Lulus KKM \\
\hline 7 & 13808 & 84 & Lulus KKM \\
\hline 8 & 13816 & 71 & Tidak Lulus KKM \\
\hline 9 & 13809 & 78 & Tidak Lulus KKM \\
\hline 10 & 13801 & 97 & Lulus KKM \\
\hline 11 & 13805 & 88 & Lulus KKM \\
\hline 12 & 13813 & 87 & Lulus KKM \\
\hline 13 & 13800 & 97 & Lulus KKM \\
\hline 14 & 13802 & 90 & Lulus KKM \\
\hline 15 & 13815 & 83 & Lulus KKM \\
\hline 16 & 13899 & 95 & Lulus KKM \\
\hline 17 & 13811 & 88 & Lulus KKM \\
\hline 18 & 13804 & 96 & Lulus KKM \\
\hline
\end{tabular}

Hasil belajar siswa menulis teks eksplansi pada siklus I pada Tabel 3 dikonvesikan ke dalam skala lima pada Tabel 4.

Tabel 4 Skala lima

\begin{tabular}{lll}
\hline Rentang nilai & Kategori & Jumlah siswa \\
\hline $91-100$ & Sangat Baik & 7 \\
$81-90$ & Baik & 3 \\
$71-80$ & & \\
$61-70$ & Cukup Baik & \\
$51-60$ & & \\
$41-50$ & Kurang Baik & \\
$31-40$ & & \\
$21-30$ & Tidak Baik & \\
$11-20$ & & 88,4 \\
$1-10$ & & 82 \\
& & 15 \\
Nilai rerata & & 3 \\
Nilai KKM & & $83,3 \%$ \\
Siswa lulus KKM & & \\
Siswa Tidak Lulus KKM & & \\
Persentasi ketuntasan klasikal &
\end{tabular}

Tabel di atas menunjukkan bahwa nilai rerata keterampilan menulis teks eksplanasi siswa pada siklus II ini sebesar 88,4 dan persentasi ketuntasan klasikal sebesar 83,3\%. Berdasarkan hasil ini keterampilan menulis teks eksplanasi siswa mengalami peningkatan dan melampaui ketuntasan klasikal yang ditetapkan, yakni sebesar $80 \%$.

Langkah-langkah penerapan model pembelajaran PBL dengan bantuan media video dilaksanakan oleh peneliti sesuai dengan yang tertera pada RPP yang telah disusun secara kolaboratif antara peneliti 
dan guru pamong. Berdasarkan hasil observasi oleh observer, peneliti melaksanakan semua langkahlangkah pembelajaran yang tertulis pada RPP.

Respons siswa terhadap pembelajaran menunjukkan bahwa $85 \%$ siswa memberikan respons positif. Terjadi penurunan pada siklus II ini. Walau demikian, respons siswa pada siklus II ini masih terkategori sangat baik. Ini dapat diartikan bahwa siswa menganggap pembelajaran sangat bermakna bagi mereka. Berdasarkan paparan hasil penelitian pada siklus II ini, dapat disimpulkan bahwa telah terjadi peningkatan keterampilan menulis teks eksplanasi siswa kelas XI SMA Negeri 1 Singaraja. Peningkatan ini ditandai dari meningkatnya ketuntasan klasikal, yakni 33,3\% pada siklus I naik menjadi $83,3 \%$ pada siklus II. Dengan demikian, penelitian ini dihentikan.

Hasil penelitian siklus I belum berhasil meningkatkan keterampilan menulis teks eksplanasi siswa. Nilai rata-rata yang diperoleh siswa sebesar 77,4. Dengan KKM sebesar 82, hanya 6 siswa yang lulus KKM dan 12 siswa tidak lulus KKM. Dengan jumlah tersebut, dapat dipersentasikan bahwa ketuntasan klasikal hanya sebesar $33,3 \%$.

\section{Pembahasan}

Ketidakberhasilan siswa dalam menulis teks eksplanasi diidentifikasi penyebabnya. Berdasarkan hasil observasi yang dilakukan oleh observer terlihat bahwa hanya satu item yang tidak dilakukan oleh guru saat pembelajaran berlangsung, yakni memberikan motivasi kepada siswa sebelum masuk ke inti pembelajaran. Walau item ini tergolong penting, tetapi item ini tidak memberi pengaruh yang signifikan terhadap peningkatan keberhasilan belajar siswa. Bahkan, respons siswa terhadap pembelajaran menunjukkan $89 \%$ positif. Persentasi ini berada dalam kategori sangat baik. Untuk itu, bisa dikatakan bahwa secara prosedur guru telah melakukan terbaik pada saat pembelajaran. Oleh sebab itu, akar permasalahan yang dihadapi siswa perlu dikaji lebih mendalam.

Berdasarkan tulisan siswa terlihat bahwa ada beberapa yang menjadi kelemahan siswa saat menulis teks eksplanasi. Kelemahan siswa tersebut diurutkan seperti yang terlihat di bawah ini. 1) Siswa belum sepenuhnya mengikuti kerangka tulisan saat menulis teks sehingga tulisannya tidak terstruktur, 2) Siswa tampak kesulitan mengembangkan ide pokok paragraf. Terlihat pada tulisannya yang sering menggabungkan dua ide pokok paragraf menjadi satu paragraph, 3) Siswa belum memahami penggunaan kalimat efektif. Terlihat pada tulisannya yang panjang-panjang dan berbelit-belit. Bahkan, hanya satu kalimat dalam satu paragraph, 4) Siswa sering terbalik dalam penggunaan kata depan di dan imbuhan di-., 5) Siswa belum memahami sepenuhnya aturan penulisan huruf kapital pada tulisan.

Kelemahan siswa di atas sejalan dengan hasil angket yang diisi siswa pada poin kesulitan siswa saat mengikuti pembelajaran. Hasil angket menunjukkan ada empat hal yang dianggap siswa sulit ketika menulis teks eksplanasi. Keempat hal tersebut adalah 1) siswa kesulitan dalam merangkai kalimat efektif dalam sebuah paragraf, 2) siswa kesulitan dalam menentukan struktur teks, 3) siswa kesulitan dalam menggunakan ejaan yang tepat, dan 4) siswa kesulitan dalam mengembangkan ide pokok paragraf.

Oleh karena itu, setelah berembuk dengan guru pamong, diputuskan bahwa akan dilakukan perbaikan pada siklus II. Hal-hal yang diperbaiki pada siklus selanjutnya adalah sebagai berikut. 1) Siswa akan diarahkan untuk mencermati ulang pertanyaan yang wajib diisi oleh siswa setelah menonton video. Pertanyaan itu sesungguhnya adalah kerangka teks eksplanasi yang akan disusun siswa. Untuk itu, siswa wajib memahami maksud pengerjaan LKS itu dan siswa wajib memahami kerangka teks berdasarkan LKS yang dikerjakannya, 2) Siswa akan dibimbing untuk mampu menyusun kalimat penjelas berdasarkan kalimat utama yang disediakan menjadi sebuah paragraph, 3) Siswa akan dibimbing untuk memperbaiki kalimat yang tidak efektif menjadi kalimat efektif, 4) Siswa akan dibimbing mengenai penggunaan kata depan di dan imbuhan $d i-$, 5) Siswa akan dibimbing mengenai penggunaan huruf kapital pada kalimat.

Siklus II dilaksanakan pada 5 September 2017. Siklus ini hanya dilakukan dalam satu kali pertemuan. Pertemuan ini diawali dengan pemaparan hal-hal yang perlu diperbaiki siswa dalam menulis teks eksplanasi seperti yang telah direncanakan. Kemudian, dilanjutkan dengan pengambilan data.

Berdasarkan hasil observasi dari observer, pelaksanaan pembelajaran telah dilakukan oleh guru dengan sistematis dan semua langkah pembelajaran telah dilakukan. Selain itu, tidak ditemukan hal-hal yang perlu diperbaiki pada saat pelaksanaan pembelajaran. Namun, respons siswa terhadap pembelajaran pada siklus II ini menurun. Pada siklus I sebesar $89 \%$ siswa menganggap pembelajaran positif, sedangkan pada siklus II ini sebesar 85\% siswa menganggap pembelajaran positif. Walaupun terjadi penurunan, secara kategori, respons siswa ini masih dalam kategori sangat baik. Dengan kata lain, pembelajaran yang dilakukan oleh guru sangat baik. Penurunan respons siswa ini bisa saja terjadi karena siswa merasa jenuh karena pembelajaran harus diulang-ulang.

Hasil siklus II berdasarkan hasil menulis teks eksplanasi oleh siswa menunjukkan nilai rata-rata yang diperoleh sebesar 88,4. Siswa yang lulus KKM sebanyak 15 orang dan yang belum lulus KKM sebanyak 3 orang. Persentasi ketuntasan klasikal sebesar 83,3\%. Persentasi ketuntasan klasikal ini 
menunjukkan bahwa penelitian ini sudah melampaui yang diharapkan, yakni 80\%. Dengan kata lain, siklus II ini telah berhasil.

Siklus II ini dinyatakan telah berhasil berdasarkan ketuntasan klasikal. Namun, secara individu, masih ada tiga siswa yang belum dinyatakan berhasil. Walaupun ketiga siswa ini belum berhasil, mereka telah menunjukkan peningkatan dalam pembelajaran jika dilihat dari nilai yang mereka peroleh pada siklus I dan II.

Selain hal yang telah dipaparkan di atas, hasil siklus II berdasarkan angket yang diisi oleh siswa terkhusus pada poin kelemahan yang dihadapi siswa saat pembelajaran, masih diperoleh masalah yang dihadapi oleh siswa saat pembelajaran. Masalah yang mereka tuliskan hampir mirip dengan masalah yang mereka sebutkan pada siklus I, yakni 1) siswa kesulitan dalam merangkai kalimat efektif dalam sebuah paragraf, 2) siswa kesulitan dalam menentukan struktur teks, 3) siswa kesulitan dalam menggunakan ejaan yang tepat, dan 4) siswa kesulitan dalam mengembangkan ide pokok paragraph. Namun ada siswa yang menuliskan berbeda dari respons siklus I, yakni tidak ada masalah.

Masalah yang dituliskan siswa pada angket respons ini bisa saja terjadi pengulangan pada kedua siklus karena beberapa siswa memang mengalami kesulitan dalam hal ini. Perlu juga disampaikan bahwa peneliti memasukkan hasil respons untuk poin kesulitan ini hanya sebagai bahan peringatan bahwa walaupun penelitian ini sudah dapat dikatakan berhasil tetapi faktanya tidak semua siswa yang berhasil. Yang berhasil adalah sebagian besar. Jadi, kesulitan yang dimaksud pada hasil angket ini memiliki korelasi dengan hasil belajar siswa yang tidak sepenuhnya berhasil. Dengan kata lain, siswa yang belum mampu sama sekali menulis teks eksplanasi dengan baik kemungkinan menuliskan kesulitan seperti hal di atas. Siswa yang sudah mampu menulis teks eksplanasi dengan baik kemungkinan menuliskan tidak punya masalah dalam hal menulis teks ini. Atau bisa juga, siswa yang sudah dikategorikan mampu menulis teks eksplanasi, tetapi dia masih merasa memiliki sedikit kesulitan dalam hal menulis teks ini maka kemungkinan menuliskan masalah seperti di atas. Oleh sebab itu, hasil penelitian ini tidak dapat dikatakan mampu meningkatkan hasil belajar pada seluruh siswa. Namun, penelitian ini mampu menunjukkan terjadinya peningkatan hasil belajar siswa dari siklus I ke siklus II.

Hal-hal yang paparkan di atas adalah seputar hasil penelitian ini dan korelasinya dengan hasil angket dan hasil observasi oleh observer. Secara ringkas peningkatan hasil belajar menulis teks ekspalansi siswa kelas XI IIS SMA Negeri 1 Singaraja dapat dilihat pada tabel di bawah ini.

Tabel 3. Perbandingan hasil belajar menulis teks eksplanasi siswa tiap siklus

\begin{tabular}{lcc}
\hline \multicolumn{1}{c}{ Aspek yang Dibandingkan } & Siklus I & Siklus II \\
\hline Nilai rata-rata & 77,4 & 88,4 \\
Ketuntasan klasikal & $33,3 \%$ & $83,3 \%$ \\
\hline
\end{tabular}

Tabel diatas disajikan dalam bentuk grafik yang dapat dilihat pada Gambar 1.

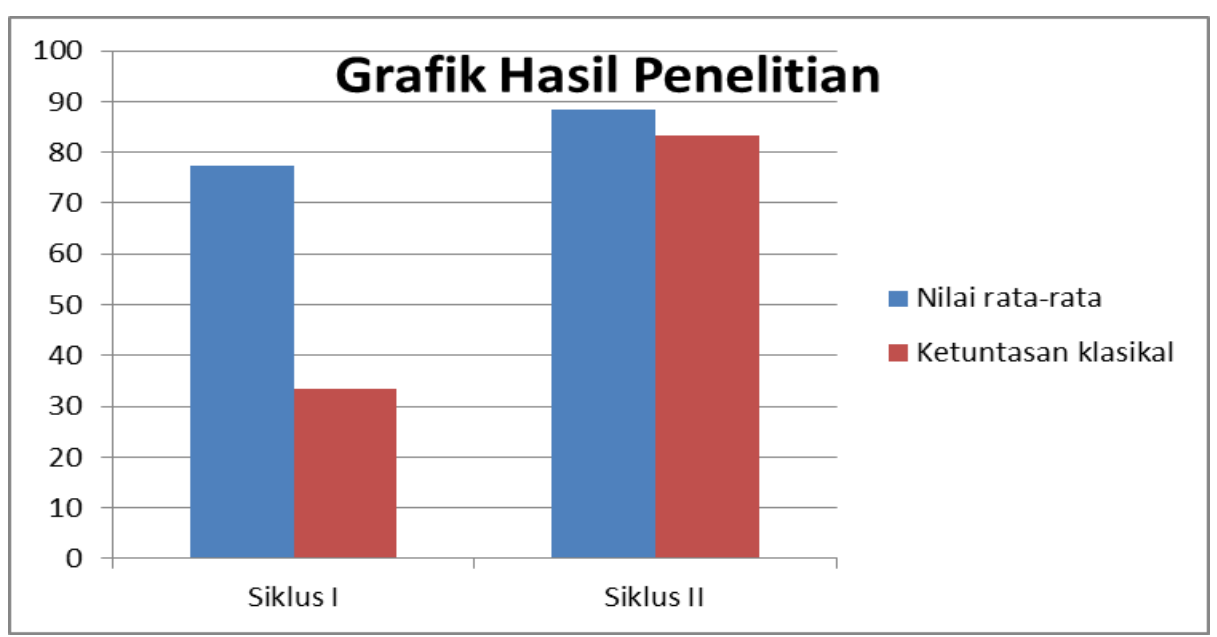

Gambar 1. Grafik Hasil Penelitian 
Hasil penelitian ini diperkuat oleh beberapa teori yang menyatakan bahwa pembelajaran berbasis masalah adalah suatu pendekatan pembelajaran yang menggunakan masalah dunia nyata sebagai suatu konteks bagi siswa untuk belajar tentang berpikir kritis dan keterampilan pemecahan masalah serta untuk memperoleh pengetahuan dan konsep yang esensi dari materi pelajaran Ashad, (2013). Menurut Trianto (2007), melalui model ini, siswa dapat memperoleh pengetahuan dengan melakukan kegiatan pemecahan masalah sehingga konsep yang dipelajari dapat diterima dan memahami informasi yang telah diterima serta menghubungkannya dengan kehidupan sehari-hari. Dengan demikian, siswa tidak hanya mengusai teori saja akan tetapi dapat mengaplikasikan apa yang mereka pelajari tersebut dalam kehidupan sehari-hari. Hal ini memperkuat teori bahwa model pembelajaran berbasis masalah adalah interaksi antara stimulus dan respons, merupakan hubungan antara dua arah belajar dan lingkungan. Adapun penelitian sebelumnya yang mendukung penelitian ini yaitu Kharida (2009) menunjukkan bahwa dengan menerapkan model pembelajaran berbasis masalah dapat meningkatkan aktifitas dan hasil belajar siswa. Hasil penelitan Ashad (2013) menyatakan bahwa dengan menerapkan model pembelajaran berbasis masalah disimpulkan terdapat perbedaan yang signifikan antara rata-rata skor tes akhir kelas eksperimen dengan kelas kontrol pada siswa kelas XI SMAN 5 Palu.

Dari Hasil penelitian yang dipaparkan di atas jika dibandingkan dengan penelitian yang dilakukan oleh Noviani (2015) maka hasil penelitian ini lebih baik. Penelitian yang dilakukan oleh Noviani berjudul Peningkatan Keterampilan Menyusun Teks Eksplanasi secara Tertulis Menggunakan Model Pembelajaran Berbasis Masalah (Problem Based Learning) pada Peserta Didik Kelas VII A SMP Negeri 19 Tegal Tahun Pelajaran 2014/2015. Hasilnya adalah nilai rerata pada siklus I sebesar 73,03 dan naik pada siklus II menjadi 84,19 . Sedangkan, penelitian ini memperoleh nilai rata-rata sebesar 77,4 pada siklus I dan naik pada siklus II menjadi 88,4. Perbedaan hasil ini bisa terjadi karena penelitian ini menggunakan model PBL dan media video sebagai solusi untuk meningkatkan keterampilan menulis teks eksplanasi siswa, sedangkan penelitian Noviani hanya menggunakan model PBL sebagai satu-satunya solusi untuk meningkatkan ketrampilan menulis teks eksplanasi siswa. Selain itu, subjek penelitian ini juga berbeda sehingga hasilnya juga memungkinkan berbeda.

Bukan hanya Noviani, hasil penelitian ini juga tergolong lebih baik dibandingkan penelitian yang dilakukan oleh Andyani, dkk (2016). Penelitian yang dilakukan oleh Andyani, dkk mengangkat judul Peningkatan Kemampuan Menulis Teks Eksplanasi dengan Menggunakan Media Audiovisual pada Siswa Sekolah Menengah Pertama. Hasilnya adalah terjadi peningkatan kemampuan menulis teks eksplanasi siswa dengan rata-rata skor 74,61 pada siklus I menjadi 84,42 pada siklus II. Sedangkan, penelitian ini memperoleh nilai rata-rata sebesar 77,4 pada siklus I dan naik pada siklus II menjadi 88,4. Perbedaan hasil ini bisa terjadi karena penelitian ini menggunakan model PBL dan media video sebagai solusi untuk meningkatkan keterampilan menulis teks eksplanasi siswa, sedangkan penelitian Andyani, dkk hanya menggunakan media audiovisual sebagai satu-satunya solusi untuk meningkatkan keterampilan menulis teks eksplanasi siswa. Selain itu, subjek penelitian ini juga berbeda sehingga hasilnya juga memungkinkan berbeda.

Terakhir, hasil penelitian ini jika dibandingkan dengan hasil penelitian yang dilakukan oleh Oktarina (2015) maka hasil penelitian Oktarina lebih baik. Penelitian Oktarina berjudul Peningkatan Keterampilan Menyusun Teks Eksplanasi dengan Model Investigasi Kelompok dan Media Audiovisual pada Peserta Didik Kelas VII A SMP Negeri 1 Ungaran. Hasil yang diperolehnya adalah terjadi peningkatan keterampilan menyusun teks eksplanasi oleh siswa, yakni rerata persentase pada siklus I sebesar 69.04\% menjadi $92.82 \%$ pada siklus II. Sedangkan, penelitian ini memperoleh nilai rata-rata sebesar 77,4 pada siklus I dan naik pada siklus II menjadi 88,4. Perbedaan hasil ini bisa saja terjadi karena model pembelajaran yang diterapkan berbeda dan subjek penelitian juga berbeda. Yang sama dari penelitian ini adalah penerapan media video atau audiovisual yang dipadukan dengan model pembelajaran.

Berdasarkan hasil perbandingan di atas dapat disimpulkan bahwa hasil belajar siswa dalam menulis teks eksplanasi akan lebih baik jika menerapkan model pembelajaran dan dipadukan dengan media pembelajaran.

\section{Simpulan dan Saran}

Simpulan penelitian ini adalah sebagai berikut. (1) Keterampilan menulis teks eksplanasi siswa kelas XI IIS SMA Negeri 1 Singaraja dengan menerapkan model pembelajaran berbasis masalah dengan bantuan media video meningkat. Terlihat dari nilai rata-rata pada siklus I sebesar 77,4 naik menjadi 88,4 pada siklus II. (2) Proses pelaksanaan pembelajaran dalam meningkatkan keterampilan menulis teks eksplanasi siswa kelas XI IIS SMA Negeri 1 Singaraja ini mengacu pada RPP yang disusun peneliti dan guru secara kolaboratif. Berdasarkan hasil observasi yang dilakukan oleh observer, langkah-langkah pembelajaran yang ada di RPP dilaksanakan oleh peneliti secara sistematis. (3) Respons siswa terhadap 
pembelajaran berada pada kategori sangat baik, yakni 89\% siswa memberi tanggapan positif pada siklus I dan $85 \%$ siswa memberi tanggapan positif pada siklus II.

Berdasarkan hasil dan proses penelitian ini, beberapa saran yang ingin disampaikan adalah sebagai berikut. (1) Pembelajaran menulis teks eksplanasi akan lebih baik hasilnya jika menerapkan model pembelajaran dan dipadukan dengan media pembelajaran. Salah satu model dan media pembelajaran tersebut adalah model pembelajaran berbasis masalah dengan bantuan media video. (2) Hasil penelitian ini dapat dijadikan salah satu referensi guru bahasa Indonesia untuk diaplikasikan kepada peserta didik pada materi menulis teks eksplanasi. (3) Hasil penelitian ini tidak tidak dapat digeneralisasi karena perbedaan karakter siswa pada setiap sekolah, tetapi hasil penelitian ini dapat dijadikan sebagai bahan perbandingan. (4) Disarankan kepada guru atau peneliti yang lain yang tertarik melakukan penelitian sejenis untuk membuat perbandingan antara model PBL ini dengan model lain dalam menulis teks eksplanasi.

\section{Daftar Rujukan}

Agustini, P. P., \& Kristiantari, M. G. R. (2016). Penerapan Model Pembelajaran Berbasis Masalah Berbantuan Media Audio Visual Untuk Meningkatkan Hasil Belajarketerampilan Menyimak Tema Sejarah Peradaban Indonesia Pada Siswa Kelas V Sdn 8 Sumerta. . E-Journal PGSD Universitas Pendidikan Ganesha, 4(1).

Andriani, Mestawaty, A. A. dan R. I. P. (2015). Penerapan Model Pembelajaran Berbasis Masalah Dalam Meningkatkan Hasil Belajar Siswa Tentang Pengaruh Gaya Terhadap Gerak Benda di Kelas IV SDN 1 Ogowele. Jurnal Kreatif Tadulako Online, 5(5), 79-92.

Andyani, Novita , Kundharu Saddhono, Y. M. (2016). Peningkatan kemampuan menulis teks eksplanasi dengan menggunakan media audiovisual pada siswa sekolah menengah pertama. Jurnal Penelitian Bahasa, Sastra Indonesia Dan Pengajarannya, 4(2).

Ariningsih, Nur Endah, D. (2012). Analisis Kesalahan Berbahasa Indonesia Dalam Karangan Eksposisi Siswa Sekolah Menengah Atas. Jurnal Penelitian Bahasa, Sastra Indonesia Dan Pengajarannya, 1(1).

Dewi, Ni Pt. Asrika Maha, I Kt. Dibia, D. N. S. (2013). Pengaruh Model Pembelajaran Problem Based Learning (PBL) Berbantuan Media Video Terhadap Hasil Belajar IPA Kelas IV SD Negeri Pergung. MIMBAR PGSDUniversitas Pendidikan Ganesha, 1(1).

Gultom, P. (2014). Pengaruh Penerapan Model Pembelajaran Berbasis Masalah Terhadap Kemampuan Menulis Teks Eksplanasi Siswa Kelas VII SMP Santo Ignasius Medan Tahun Pembelajaran 2013/2014. Jurnal Bahasa Unimed, 3(4), 1-11.

Kemdikbud. (2016). Silabus Mata Pelajaran Sekolah Menengah Atas/Madrasah Aliyah/Sekolah Menengah Kejuruan/Madrasah Aliyah Kejuruan (Sma/Ma/Smk/Mak) Mata. Kemendikbud. Jakarta: Kemendikbud.

Kharida, L. A., Rusilowati, A., \& Pratiknyo, K. (2009). Penerapan model pembelajaran berbasis masalah untuk peningkatan hasil belajar siswa pada pokok bahasan elastisitas bahan. Jurnal Pendidikan Fisika Indonesia Universitas Negeri Semarang, 5(1).

Natalia, D. S. (2017). Penerapan Model Pembelajaran Berbasis Masalah Dengan Bantuan Media Video Untuk Meningkatkan Keterampilan Menulis Teks Eksposisi Siswa. Jurnal Penelitian Dan Pengembangan Pendidikan Undiksha, 1(2).

Oktarina, R. (2015). Eksplanasi Dengan Model Investigasi Kelompok Dan Media Audiovisual Pada Peserta Didik Kelas Vii a Smp Negeri 1 Ungaran. Jurnal Online Unnes, 1(1).

Primiani, N. (2012). Penerapan model pembelajaran berbasis masalah untuk meningkatkan proses dan hasil belajar pada perkuliahan fisiologi hewan. Jurnal Pendidikan Biologi FP Mipa Ikip Pgri Madiun, 1(1).

Putri, Muthia Ichsani, Insih Wilujeng, W. S. (2017). Pengaruh Model Problem Based Learning Berbantuan 
Video Terhadap Keterampilan Berpikir Kritis Siswa Smp. E-Journal Pendidikan IPA UNY, 1(1).

Ramadhanti, D. (2017). Peningkatan Keterampilan Menyusun Teks Eksplanasi secara Tertulis Menggunakan Model Pembelajaran Berbasis Masalah (Problem Based Learning) pada Peserta Didik Kelas VII A SMP Negeri 19 Tegal Tahun Pelajaran 2014-2015. JURNALGRAMATIKA, 3(1).

Ramadhanti, D., Program, D., Pendidikan, S., \& Indonesia, S. (2017). Penerapan Model Kooperatif Tipe Circ Dalam Pembelajaran Menulis Narasi Siswa Kelas Vii Smp Negeri 2 Lembah Gumanti. Gramatika.

Rusman. (2012). Model-model pembelajaran: Mengembangkan profesionalisme guru.

S, M. A., Ali, M., \& Pasaribu, M. (2013). Pengaruh Model Pembelajaran Berbasis Masalah terhadap Hasil Belajar Fisika Pada Siswa Kelas XI SMA Negeri 5 Palu. Jurnal Pendidikan Fisika Tadulako Universita Tadaluko Palu, 1(2), 39-43.

Saadah. (2017). Penerapan Model Pembelajaran Ktri Untuk Meningkatkan Kemampuan Menulis Teks Laporan Smp Padangratu. . Jurnal Online Pendidikan Bahasa Dan Sastra, 1(1).

Sariadi, N. K., Pudjawan, K., Syahruddin, H., Pendidikan, J., Pendidikan, G., Dasar, S., ... Ganesha, U. P. (2014). Penerapan Model Pembelajaran Berbasis Masalah Untuk Meningkatkan Hasil Belajar IPA Kelas V SD. MIMBAR PGSDUniversitas Pendidikan Ganesha, 2(1). Retrieved from http://ejournal.undiksha.ac.id/index.php/JJPGSD/article/download/2562/2185

Somodana, W., Sutresna, I. B., \& Ganesha, U. P. (2015). Penerapan Model Pembelajaran Berbasis Masalah ( Problem Based Learning ) Dalam Pembelajaran Menulis. Pendidikan Bahasa Dan Sastra Indonesia Undiksha, 3(1).

Sriani, N. K., Sutama, M., Ayu, I., Darmayanti, M., Pendidikan, J., Dan, B., ... Seni, D. (2015). Penerapan Model Pembelajaran Experiential Learning Untuk Meningkatkan Kemampuan Menulis Paragraf Deskripsi Pada Siswa Kelas Vii B Smp Negeri 2Tampaksiring. Journal Universitas Pendidikan Ganesha Jurusan Pendidikan Bahasa Dan Sastra Indonesia, 3(1), 1-11.

Trianto. (2007). Model-Model Pembelajaran Inovatif Berorientasi Konstruktivistik. Jakarta: prestasi pustaka.

Ulfah, W. (2014). Pengaruh Penerapan Model Pembelajaran Berbasis Masalah Terhadap Kemampuan Menulis Teks Eksposisi oleh Siswa Kelas X SMA Negeri 1 Babalan Tahun Pembelajaran 2013-2014. Jurnal Online, 1(1).

Utomo, T., Wahyuni, D., \& Hariyadi, S. (2014). Pengaruh Model Pembelajaran Berbasis Masalah (Problem Based Learning) Terhadap Pemahaman Konsep dan Kemampuan Berpikir Kreatif Siswa ( Siswa Kelas VIII Semester Gasal SMPN 1 Sumbermalang Kabupaten Situbondo Tahun Ajaran 2012 / 2013 ). Jurnal Edukasi eNEJ, 1(1), 5-9. 